\title{
The Influence of Emotional Intelligence, Work Climate and Work Discipline on Employee Performance
}

\author{
Rosy Mutia Satrina ${ }^{1 *}$, Yunia Wardi ${ }^{2}$, Rosyeni Rasyid ${ }^{3}$ \\ 1,2.3 Universitas Negeri Padang, Padang, Indonesia \\ *Corresponding author. Email: rosymutiasatrina@gmail.com
}

\begin{abstract}
This study aims to determine and analyse the effect of emotional intelligence, work climate and work discipline on the performance of the employees of the Islamic Hospital Ibnu Sina Padang. The research design is a design of causality. The population of this study were all employees at Islamic Hospital Ibnu Sina Padang, with a total of 295 employees with a sample of 170 people. The sampling technique was proportional cluster random sampling. This study uses primary data collected by a questionnaire. As a dependent variable is employee performance and an independent variable are emotional intelligence, work climate and work discipline. The research hypothesis testing was analysed using multiple regression. This study found that emotional intelligence, work climate and work discipline partially or collectively affect employee performance significantly.
\end{abstract}

Keywords: Emotional intelligence, Work climate and work discipline, Employee performance.

\section{INTRODUCTION}

In competitive era, skilled, expert, professional and highly accomplished human resources are the dream of all organizations, both private and government. The target to be achieved by having qualified human resources is work productivity or a high performance.

Hospitals are an integral part of the entire health care system serving patients with various types of services. A person's health has a major role in improving the standard of life of the community, in providing optimal health services in hospitals, quality resources are needed, by using existing resources it is hoped that the hospital can produce a maximum output in the form of products or services to improve services. For these problems, it must be realized that the success of the hospital is partly due to human resources, so that human resources are seen as an asset of the hospital, even as an investment in the hospital if the personnel are skilled.

A hospital is a business in the field of health services by utilizing treatment facilities, drugs and other medical support. This hospital business is a business that is growing rapidly and its management must be carried out properly in order to continue to compete in an increasingly competitive environment. Along with the development of science and the existence of the latest government regulations, the performance of hospitals that are able to serve patients is increasingly demanded, precisely and quickly.

This employee's performance is of course very much influenced by many factors. In this study, the authors suspect that the factors that are likely to be the most dominant in influencing employee performance are employee emotional intelligence, work climate and performance discipline.

Performance as a standard that describes the operational efficiency of an enterprise, parts of the unit, and executing based on perfection and grille have predetermined. Which is the comparison between the work produced with predetermined conditions and the work process itself focuses more on the results of the work [1]. According to the literature on behaviour in company management, performance is referred to as the number of activities and the quality of the work of the goods or services provided by the personnel who carry out the office's affairs [2].

According to [3] performance is the output produced by the functions or indicators of a job or profession within a certain time. According to [4]. That work output is a behavioural reality provided by workers as a result of the results in accordance with their job description in the company. That is the importance of employee performance towards the company's vision. 
According to [5] the definition of performance in general is what employees do and don't do. [6] states that performance is the work result of human behaviour/activities directed at the implementation of organizational tasks assigned to it. [7] also defines performance as the achievement of quality results and the amount of work performed by an employee in carrying out his duties according to the job description assigned to him.

It can be concluded that the final result is something work performed by employees both in quantity and quality to complete the task which will be accountable.

According to [5] intelligence, self-motivation, getting support, the job itself, and employee relations with the organization. Meanwhile, according to [8] there are 3 individual factors that influence the performance that comes from within them, namely: 1) high intellectual ability, 2) emotional management ability, 3) spiritual ability.

According to [2] Aspects that cause employee performance to change are the receipt of salaries and benefits, how to lead to subordinates, work commitment, environment, working conditions, institutions culture, participation in the organization, and timeliness. Furthermore, other factors that influence performance according to [9] are the same as Lutans opinion coupled with organizational climate

[1] employee performance is influenced by ability, motivation, work behaviour, organizational culture and employee interests as well as people's acceptance of the work for which they are responsible. Other factors that affect organizational performance are non-physical factors, such as organizational climate concerning work comfort and satisfaction, interpersonal relationships at work and the ability to work, as well as the physical work environment such as the completeness of facilities and office layout.

\section{METHOD}

The research design is a design of causality. The population of this study were all employees at RSI Ibnu Sina Padang, with a total of 295 employees with a sample of 170 people. The sampling technique was proportional cluster random sampling. This study uses primary data collected by a questionnaire. The independent variable is employee performance and the independent variable is emotional intelligence, work climate and work discipline. Hypothesis testing data analysis technique is multiple regression.

\section{RESULTS AND DISCUSSION}

This study aims to examine how employee emotional, hospital work climate and hospital discipline, performance labour which is analysed using multiple regression. The results of multiple linear regression data analysis based on the data that have been collected can be seen in the following table 1 .

Table 1. Results of multiple regression analysis

\begin{tabular}{|l|l|c|c|c|}
\hline $\begin{array}{l}\text { Dependent } \\
\text { Variable }\end{array}$ & $\begin{array}{l}\text { Independent } \\
\text { Variable }\end{array}$ & Coefficient & t stat & Sig \\
\hline $\begin{array}{l}\text { Employee } \\
\begin{array}{l}\text { Performance } \\
(\mathrm{Y})\end{array}\end{array}$ & Constanta (a) & 1.068 & & \\
\cline { 2 - 5 } & $\begin{array}{l}\text { Emotional } \\
\text { Intelligence } \\
\left(\mathrm{X}_{1}\right)\end{array}$ & 0.148 & 1.996 & 0.048 \\
\cline { 2 - 5 } & $\begin{array}{l}\text { Work } \\
\text { Climate }\left(\mathrm{X}_{2}\right)\end{array}$ & 0.190 & 2.468 & 0.015 \\
\cline { 2 - 5 } & $\begin{array}{l}\text { Work } \\
\text { Discipline } \\
\left(\mathrm{X}_{3}\right)\end{array}$ & 0.319 & 4.814 & 0.000 \\
\cline { 2 - 5 } & $\begin{array}{l}\text { F statistic }=42.676 \\
\text { F sig. }=0.000 \\
\text { RSquare }=0.435\end{array}$ & & \\
\hline
\end{tabular}

After analysing the data, a multiple regression equation can be made from the research results as follows:

$$
\begin{aligned}
& \mathrm{Y}=\alpha+\beta 1 \mathrm{X} 1+\beta 2 \mathrm{X} 2+\beta 3 \mathrm{X} 3+\mathrm{e} \\
& \mathrm{Y}=1,068+0,148 \mathrm{X} 1+0,190 \mathrm{X} 2+0,319 \mathrm{X} 3
\end{aligned}
$$

The coefficient value of each variable in the multiple linear regression equation above can be interpreted as follows. A constant value of 1.068 indicates the value of the employee performance variable before or without being influenced by the variable emotional intelligence, work climate and work discipline, where if the variables of emotional intelligence, work climate and work discipline are zero, the value of the dependent variable is only 1.068 .

The regression coefficient value of the emotional intelligence variable is 0.148 which is positive, indicating the direction of the influence of emotional intelligence on employee performance is positive or unidirectional. If the value of the emotional intelligence variable increases by one unit, it will increase the value of the performance variable by 0.148 in each one, assuming the other variables are constant.

The regression coefficient value of the work climate variable is 0.190 which is positive which indicates the effect is in the positive direction or direction. If the value of the work climate variable increases by one unit, it will add the variable value $(\mathrm{Y})$ by 0.190 in each one, assuming other variables are constant.

The regression coefficient value of the work discipline variable is 0.319 which is positive, indicating the direction of the effect of labour discipline on the capacity of workers to be either positive or unidirectional. If the value of the work discipline variable increases by one unit, this will push up the value of the performance variable by 0.319 in each one, assuming other variables are constant. 
The value $\mathrm{R}$ square is $0,0.435$, This means that emotional intelligence, work climate and work discipline affect employee performance by $43.5 \%$, and $56.5 \%$ are influenced by other variables.

\subsection{Discussion}

\subsubsection{Emotional Intelligence}

From hypothesis one, it is found that emotional intelligence has a positive effect. The higher the level of emotional intelligence of employees, of course, will improve employee performance at work.

The findings show that emotional intelligence affects the performance of employees, this is because if employees are able to control themselves and have empathy for others in carrying out services or work, it will certainly encourage an increase in employee performance. The form of emotional intelligence is in the form of recognition of one's own abilities, ability to control one's emotions, being able to provide encouragement and self-motivation, understanding the social environment and other people's situations.

The research findings are supported by the opinion of [10]; [11]; [12]; [13], which states that emotional intelligence can affect a person's success at work.

\subsubsection{Work Climate}

Testing the second hypothesis results that the environmental situation at work affects the rhythm of employee performance. It can be interpreted as more conducive to the work climate, which will certainly increase a person's morale in carrying out their duties.

This study proves that the work climate has a significant effect on employee performance, this happens if a better work climate is felt by employees, which will certainly the employee performance will rise. Where, if employees are given autonomy and flexibility in their work and are given trust and support at work, it will certainly encourage an increase in employee performance.

From these findings it is known that the work climate as part of the perception of members of an organization, both individuals and groups and other parties who regularly interact with the organization about the organization's internal environment which will affect the attitudes and behaviour of organizational members, and influence high and the appearance of the employee who is not good enough to undergo the given job. The better and more conducive the work climate felt by employees will certainly be able to improve employee performance in carrying out tasks.

The findings of this study are supported by the opinion of [3] which states that employee performance is influenced by organizational climate because the work climate is the perception of organizational members (individually and in groups) regarding what exists or happens in the internal environment of the organization, which affects attitudes and behaviour. The findings of this study are relevant to the results of research which found that the work climate has a significant effect on employee performance [14].

\subsubsection{Work Discipline}

The third hypothesis, shows that work discipline is closely related to employee work results. This means that the higher the level of work discipline of employees at work will it is certain that the performance will be excellent.

The research results prove that employee performance is influenced by employee discipline, because if all employees behave, behave and act in accordance with organizational regulations, both written and unwritten, it will certainly encourage an increase in employee performance.

This study found that when all employees comply with all organizational regulations, both written and unwritten, it can improve the employee's performance at work. This compliance is in the form of compliance with working hours regulations, work standards, dress uniforms, use of facilities and work according to procedures (SOP). It can be emphasized that when employees comply with all these rules, it will certainly encourage an increase in employee performance.

Based on the research findings, it is known where labour discipline contribution is positive and beneficial to the work output because discipline in a job is the will and willingness of employees to comply with and obey all applicable rules and regulations, both written and unwritten. Good discipline reflects a person's sense of responsibility for the tasks assigned to him. This will encourage improving employee performance.

The findings of this study are supported by the opinion of [15] which states that work discipline is attitudes, habits and activity work based on the rules set by the organization. With high work discipline will encourage an increase in carrying out work. The findings of the variables studied provide relevant results which found that work discipline has a significant effect on employee performance [16].

\section{CONCLUSION}

Based on the research findings, It was found that the regulation of feelings of the heart can provide attachment to what is produced in work. This means that the level of employee performance is positively influenced by emotional intelligence. skyrocketing level of emotional intelligence of employees, of course, will improve employee performance at work. If employees are able to control themselves and have empathy for others, the employee's performance will increase. 
Work climate has a significant effect on employee performance. This means that a better work climate will certainly improve employee performance in carrying out their duties. Where, if employees are given autonomy and flexibility in their work and are given trust and support at work, it will make employee performance high.

Work discipline becomes an added value for the performance of the workforce, which means the higher the level of employee work discipline at work will certainly improve employee performance in carrying out tasks. If all employees behave, behave and act of employees in accordance with company laws, whether oral or not, of course, the performance will be good.

In an effort to improve employee performance, several suggestions were made to the leadership to do the following: 1) to increase the emotional intelligence of employees at work. 2) leadership elements pay attention to the working climate in the hospital. 3) Hospital leaders improve employee work discipline.

\section{REFERENCES}

[1] D. Gary, Human resource management. tenth edition. New Jersey: Prentice Hall. 2000.

[2] F. Luthans, Organizational behavior. New York: McGraw-hill. 2005.

[3] Wirawan, Evaluasi kinerja sumer daya manusia: teori, aplikasi dan penelitian. Jakarta: Salemba Empat. 2009.

[4] R. Veithzal and S. E. Jauvani, Manajemen sumber daya manusia untuk perusahaan: dari teori ke praktek, Jakarta: Rajagrafindo Persada, 2009.

[5] Mathis dan Jackson, Manajemen sumber daya manusia, edisi pertama, Bandung: CV Pustaka Setia, 2002

[6] A. Thomas, 7 Kinds of smart multiple intelligence, alih bahasa T. Hermaya, Jakarta: Penerbit PT Gramedia Pustaka Utama, 1999.

[7] Mangkunegara, Anwar, \& Prabu, Evaluasi kinerja sdm, cetakan 4, Bandung: Refika Aditama, 2009.

[8] Mangkunegara, Anwar, Prabu, Manajemen sumber daya manusia. perusahaan. cetakan pertama, Jakarta: Remaja Rsodakarya, 2004.

[9] Hasibuan, \& Melayu, Manajemen sumber daya manusia. Bandung: Bumi Aksara, 2007.

[10] D. Goleman, Kecerdasan emosional: mengapa EI lebih penting daripada IQ. (terjemahan oleh Hermaya). Jakarta: Gramedia Pustaka Utama. 2001.
[11] C. S. Lam and R. E. Eleanor, O'Higgins, Enhancing employee outcomes the interrelated influences of managers' emotional intelligence and leadership style. Leadership \& Organization Development Journal, 33(2), pp. 149-174, 2012

[12] S. Nayati, H. Ruhana, U. Ika, Pengaruh kecerdasan emosional terhadap kinerja (studi pada karyawan PT. Jasa Raharja cabang Jawa Timur). Jurnal Administrasi Bisnis (JAB)|36(1), 2016

[13] W. Dhyah, Pengaruh kecerdasan emosi terhadap kinerja perawat pada Rumah Sakit Panti Rapih Yogyakarta. Media Mahardhika. 15(1), 2016

[14] R, Yoeyong, Pengaruh iklim kerja terhadap kinerja pegawai administrasi pusat Universitas Padjadjaran Bandung (studi pada bagian administrasi umum UNPAD). Jurnal Manajemen Magister, 02(01), 2016

[15] E. Sutrisno, Manajemen sumber daya manusia. Jakarta: Kencana, 2009

[16] M, Fitra, Pengaruh pengawasan dan disiplin kerja terhadap kinerja karyawan pada Rumah Sakit Islam At-Taqwa Gumawang. Jurnal Kolegial, 3(1), 2017. 